\title{
Implication of light and scanning electron microscopy of foliar cuticular and palynological features in the correct identification of medicinal plants
}

Nighat Seema ${ }^{1 *}$, Muhammad Hamayun ${ }^{1}$, Asad Ullah ${ }^{2}$, Muhammad Zakaria $^{3}$, Raees Khan ${ }^{4}$ and Omerkilic ${ }^{5}$

1. Department of Botany, Abdul Wali Khan University Mardan-Pakistan

2. Centre of Plant Biodiversity, University of Peshawar-Pakistan

3. Department of Botany, Govt Post Graduate College Mardan-Pakistan

4. Zoological Survey of Pakistan, Ministry of Climate Change, Islamabad-Pakistan

5. Vocational School of Technical Sciences, University of Bingol-Turkey

*Corresponding author's email: nssema777@gmail.com

Citation

Nighat Seema, Muhammad Hamayun, Asad Ullah, Muhammad Zakaria, Raees Khan and Omerkilic. Implication of light and scanning electron microscopy of foliar cuticular and palynological features in the correct identification of medicinal plants. Pure and Applied Biology. Vol. 8, Issue 1, pp199-207. http://dx.doi.org/10.19045/bspab.2018.700177

\begin{tabular}{llll}
\hline \hline Received: 02/09/2018 & Revised: 24/10/2018 & Accepted: 26/10/2018 & Online First: 27/10/2018 \\
\hline
\end{tabular}

\section{Abstract}

Foliar epidermal anatomy and palynology of six medicinal plant species Catharanthus roseus L., Carum carvi L., Trachyspermum ammi L., Anethum graveolens L., Foeniculum vulgare Mill. and Nigella sativa L. are commonly used for different medicinal uses. Six medicinal species were used as an example and their foliar cuticular and pollen features were evaluated by light and scanning electron microscopy (SEM). Features allied to pollen grains (pollen type, colpi,and sculpture type) and foliar cuticular features (epidermis, stomata, and trichome) were found to be important examined characters. Pollen grain morphology of these medicinal plants revealed that the pollen is the prolate and per-prolate type. Their foliar epidermal anatomy revealed the presence of an anomocytic type of stomata in $C$. roseus, $C$. carvi and $N$. sativa, dicytic type in $F$. vulgare and anisocytic type in A. graveolens.

Keywords: Medicinal plants; Palynology; SEM; Taxonomic identification

\section{Introduction}

Medicinal plants are in common use in most of the developing countries [1]. Plants are morphologically similar and correct identification in crude form is very difficult. The Foliar epidermis is one of the most significant taxonomic characters from the biosystematics point of view and the taxonomic studies of a number of families are made on the basis of leaf epidermis $[2,3]$.
The significance of pollen morphology in the taxonomy of Apocynaceae has been investigated by many researchers including Guinet, Mareues, Schill Nilssons and Van Campo [4-8]. Apiaceae, a family of about 300 genera and 3000 species is cosmopolitan in distribution, mainly in northern regions [9, 10]. In Pakistan, it is represented by 56 genera and 167 species [11]. The family is of considerable economic importance for food, 
flavoring, and ornamental plants. Apiaceae also has some poisonous plants. Seeds of Apiaceae are of importance because of their essential oils. Of this, caraway seeds $(C$. carvi) are used in bread, Dill (A. graveolens) is used in flavoring dill pickles. Ranunculaceae is a large family of 50 genera and 2000 species widely distributed throughout the northern hemisphere but also in southern temperate regions [10]. In Pakistan, it is represented by 22 genera and 114 species, of which genera like Nigella, Anemone, and Aquilegia include plants of ornamental value [12]. The level of confidence in taxonomic units supported by different kinds of data is likely to be much higher than for those supported by only one kind [13]. Thus, the main objective of the study was to characterize the taxa by using multiple and complementary perspectives to supplement the traditional morphologybased description with additional markers (foliar epidermal anatomy \& palynology). The objective of the palynological studies was to provide additional knowledge about the pollen morphology of the taxa already investigated by the above-mentioned workers as well as to include additional taxa, which were not considered in the studies of previous workers. The character of spine index was used for the first time to characterize pollen of the taxa under investigation.

\section{Materials and methods}

\section{Foliar cuticular studies}

Fresh samples for the type and shape of leaf epidermal cell studies were collected from the field and prepared according to the modified method of Clark's [14], Voucher numbers are given in (Table 1). The leaves were placed in test tubes and treated with $88 \%$ lactic acid, in a water bath (Model, Memmert-91126-FRG, Germany) at $100{ }^{\circ} \mathrm{C}$ for $20-40 \mathrm{~min}$. They were then removed from the test tube into a Petri dish. A drop of lactic acid was used to soften the tissue of leaf due to which it's peeling off is made easy. Slides of both abaxial and adaxial sides of leaves were prepared and observed under light microscope. Microphotographs were taken by using a CCD digital camera (Model: DK 5000) fitted on leica light microscope (model: DM 1000). These micrographs were useful for identification and differentiation of epidermal cells on the basis of microscopic features. The leaves were prepared for scanning electron microscopy (SEM) by the standard methods described by Erdtman [15]. A leaf piece washed with acetic anhydride was directly transferred to a metallic stub and let it dry. Then it was coated with gold in a sputter chamber (Ion-sputter JFC-1100) with coating restricted to $150{ }^{\circ} \mathrm{A}$. Scanning Electron Microscopy examination was performed by Jet microscope JSM-T 200, in Centralized Science Laboratory, University of Karachi. Foliar epidermal characters like epidermal cells, stomata and trichomes were studied.

\section{Palynological studies}

For these studies, the glycerin jelly was prepared according to the modified method of Parveen and Qaiser [11]. $500 \mathrm{~mL}$ of distilled water was taken in a beaker and heated on a hot plate (model UELP Scientifica, Germany). 35 gm of gelatin was added when the temperature reached $70-80$ ${ }^{\circ} \mathrm{C}$. After an increase in temperature, it became a viscous liquid of glycerin jelly. Whole solution was kept on heating for one hour. 35 gm of glycerol was mixed in it with few crystals of phenol. Then $0.1 \%$ safranin was added with the 1/8th volume of glycerin jelly. It was stirred till uniform pink color appeared. Jelly was stabilized at room temperature. Specimens used for foliar epidermal analysis were also used as a source for polliniferous material. For processing of pollen for light and scanning microscopy, the slides were prepared by the modified procedure of Erdmann [16]. For light microscopy, the pollen grains were mounted in glycerin jelly stained with $1 \%$ safranin, on 
a glass slide. A glass coverslip was placed on the prepared pollen glycerin jelly mixture. When cooled, the glass slide was labeled and edges of the coverslip were sealed with transparent nail vanish. The prepared slides were studied under the light microscope. Pollen shape, pollen diameter, exine thickness, exine sculpturing, the height of the spine, the width of the spine at its base, spine index, inter-spinal distance and pore diameter were examined. Details of pollen morphology were based on the measurements of 10-15 grains. For SEM studies, pollen grains suspended in a drop of $40 \%$ acetic acid were transferred to clean metallic stubs and coated with gold using a JEOL JFC $1100 \mathrm{E}$ ion sputtering device. SEM observations were carried out on a JEOL microscope JSM5910. The work was carried out in the Centralized Science Laboratory, University of Karachi Pakistan. The terminology used was that of Erdmann, Moore and Punt [1618 .

\section{Results and discussion}

The detailed medicinal uses of the six investigated plants species are shown (Table 1). The foliar epidermal anatomy of $C$. roseus showed ordinary epidermal cells irregular to cuboidal, pentagonal and hexagonal to polygonal. Cell walls thick, straight, irregular or wavy. Cells compactly arranged without intracellular spaces without glands and hairs. Stomata absent adaxially or very rare. Stomata are of anomocytic type abaxially. 36 $\mu \mathrm{m}$ to $56 \mu \mathrm{m}$ long and 25-30 $\mu \mathrm{m}$ wide (Table 2). Foliar epidermal anatomy of $T$. ammi showed conspicuous costal and intercostals zonation. Ordinary epidermal cells irregular, longitudinally arranged and somewhat tubular, walls sinuous. Coastal zone with $\mathrm{Ca}-$ oxalate crystals, costal epidermal cells small, transversely flattened, compactly arranged in the form of filaments. Stomata absent coastally, prickles and glands not observed. Epidermal cells in the foliar epidermal anatomy of $A$. graveolens are irregular, polygonal to cuboidal. Cell walls are sinuous shaped. Stomata anisocytic, common on surfaces, subsidiaries cells unequal, guard cells bean-shaped (Figure 1). 50-75 $\mu \mathrm{m}$ long and 45-55 $\mu \mathrm{m}$ wide, stomatal pore $20-35 \mu \mathrm{m}$ long. Glands, prickles, and hairs not observed. In the foliar epidermal anatomy of $F$. vulgare costal and intercostals zones are distinct. Intercostals ordinary epidermal cells rectangular, tubular, cuboidal to polygonal, arranged regularly in vertical rows. Cell walls markedly sinuous, stomata dicytic, common on both surfaces, 22-30 $\mu \mathrm{m}$ long. Subsidiaries slightly unequal with irregular outline. While in the leaves of $C$. carvi zonation is absent. Epidermal cells irregular, walls wavy, eglandular adaxially. Stomata common, anomocytic, 42-52 $\mu \mathrm{m}$ long and 25-31 $\mu \mathrm{m}$ wide. Subsidiaries absent. Epidermal cells of $N$. sativa irregular in shape, angle somewhat stellate, stomata present, anomocytic, unicellular, glandular and club-shaped trichomes present. 150-200 $\mu \mathrm{m}$ long, narrowing into a prominent beak at the tip. Stomata are 60-90 $\mu \mathrm{m}$ abaxially and 40-60 $\mu \mathrm{m}$ adaxially, few abaxially and common adaxially.

The pollen grains of $C$. roseus is prolate with exine sculpturing elements elongated sideways and extending more or less parallel, forming grooves or gaps between them. $C$. roseus has the largest pollens $(57.4 \times 37.5 \mathrm{um})$ and T. ammi has the smallest pollens (Figure 2 ). The pollens are tri-colporate and about $57.4 \mu \mathrm{m}$ long and $37.5 \mu \mathrm{m}$ wide. The colpus length is about $47.4 \mu \mathrm{m}$. Pollen grains of $T$. ammi is per-prolate with exine sculpturing striate with sculpturing elements elongated and extending sideways and parallel (Table $3)$. The pollens are bi-colporate and about $13.7 \mu \mathrm{m}$ long and $8.58 \mu \mathrm{m}$ wide. The length of colpus is about $8.63 \mu \mathrm{m}$. While pollen grains of A. graveolens are bi-colporate with exine sculpturing psilate with the surface completely smooth. The pollens are about $20.9 \mu \mathrm{m}$ long and $7.67 \mu \mathrm{m}$ wide. Colpus 
length is about $12.6 \mu \mathrm{m}$. The pollen grains of $F$. vulgare is bicolporate with exine sculpturing striate with sculpturing elements much elongated and extending parallel forming gaps or grooves. Pollens are about $20.9 \mu \mathrm{m}$ long and $9.6 \mu \mathrm{m}$ wide. Colpus length is about $12.1 \mu \mathrm{m}$. The pollen grains of $C$. carvi are prolate with exine sculpturing reticulate with sculpturing elements arranged in compact networking with gaps (lumina) and muri (ridges). The pollens are bicolporate about $20.8 \mu \mathrm{m}$ long and about $10.5 \mu \mathrm{m}$ wide. Colpus length is about $12.0 \mu \mathrm{m}$. The pollen grains of Nigella sativa is spheroidal with exine sculpturing perforate with holes or depression less than $1 \mu \mathrm{m}$. The pollens are tetra-colporate and about $41.0 \mu \mathrm{m}$ long and $34.6 \mu \mathrm{m}$ wide. Colpus length is about 27.9 $\mu \mathrm{m}$. Ranunculaceae is a eurypalynous family. Pollen grains 2, 3, 4 colpate, 3 colporoidate, pantocolpate, pantoporate, inaperturate, pollen shape oblate to spherpidae, ornamentation shows variety (echinate, reticulate etc.) [15]. 5 distinct pollen types in the family on the basis of exine ornamentation and apertural types were recognized by Parveen and Qaiser [11]. The family has spinuloseexine ornamentation, the most common pattern in the Ranunculaceae [19].

Table 1. Species, local names, Part used, flowering seasons and traditional medicinal uses

\begin{tabular}{|c|c|c|c|c|c|c|}
\hline Species & $\begin{array}{l}\text { Local } \\
\text { names }\end{array}$ & $\begin{array}{l}\text { Part } \\
\text { used }\end{array}$ & $\begin{array}{l}\text { Flowerin } \\
\text { g period }\end{array}$ & $\begin{array}{l}\text { Voucher } \\
\text { No. }\end{array}$ & $\begin{array}{c}\text { Traditional } \\
\text { medicinal uses }\end{array}$ & $\begin{array}{c}\text { Morphological } \\
\text { Description }\end{array}$ \\
\hline $\begin{array}{l}\text { C. roseus (L.) } \\
\text { G. Don }\end{array}$ & Sadabahar & $\begin{array}{l}\text { Leaves } \\
\& \\
\text { flowers }\end{array}$ & $\begin{array}{l}\text { Througho } \\
\text { ut the } \\
\text { year }\end{array}$ & 126864 & $\begin{array}{l}\text { Antihyperglyce } \\
\text { mic, hypotensive } \\
\text { anti-cancer and } \\
\text { anti-diabetic }\end{array}$ & $\begin{array}{l}\text { Perennial sub-shrub, woody } \\
\text { at base, } 30-60 \mathrm{~cm} \text { tall, } \\
\text { young branches pubescent. } \\
\text { Leaves oblong } \\
\text { oblanceolate, membranous, } \\
2.5-6 \times 1.5-3 \mathrm{~cm} \text {, entire, } \\
\text { obtuse, base obtuse or } \\
\text { cuneate, glabrous or } \\
\text { sparingly hairy specially on } \\
\text { nerves beneath, shining } \\
\text { green above, paler below, } \\
\text { lateral nerves obscure; } \\
\text { petiole short, } 3-10 \mathrm{~mm} \\
\text { long, with many glands at } \\
\text { the axil. Inflorescence of } \\
\text { axillary } 1-4 \text { flowered } \\
\text { cymes, Flowers pink or } \\
\text { white, pedicel } 1-3 \text { mm long. } \\
\text { Calyx tube short, lobes } \\
\text { linear acute, } 5-7 \text { mm long, } \\
\text { hairy. Corolla tube } 20-25 \\
\text { mm long, sparsely } \\
\text { pubescent above, throat } \\
\text { densely hairy within below } \\
\text { the stamens, lobes oblong- } \\
\text { rounded, or obovate, } 15-25 \\
\text { mm long spreading Disc } \\
\text { scales higher than ovary, } 2- \\
3 \text { mm long. Ovary } \\
\text { pubescent; style } 2.5 \mathrm{~cm}\end{array}$ \\
\hline
\end{tabular}




\begin{tabular}{|c|c|c|c|c|c|c|}
\hline & & & & & & $\begin{array}{l}\text { long; stigma pentagonal. } \\
\text { Follicles } 2 \text {, slender, } \\
\text { cylindric, striated. } 15-25 \\
\text { mm long. }\end{array}$ \\
\hline $\begin{array}{l}\text { T. ammi L. } \\
\text { Sprague }\end{array}$ & Ajowain & Fruits & $\begin{array}{l}\text { Novembe } \\
\text { r-March }\end{array}$ & 12106 & $\begin{array}{l}\text { Antihyperlipide } \\
\text { mic, digestive, } \\
\text { antiseptic, spice, } \\
\text { anti-oxidants. }\end{array}$ & $\begin{array}{l}\text { Annual, } 15-50 \mathrm{~cm} \text { tall, } \\
\text { branched. Stem glabrous. } \\
\text { Leaves much divided; } \\
\text { ultimate segments filiform. } \\
\text { Involucre of 5-8 linear, } \\
\text { sometimes pinnate, bracts. } \\
\text { Rays 8-16, glabrous, } \\
\text { unequal. Involucel of 5-8 } \\
\text { linear, sometimes pinnate } \\
\text { bract-lets. Pedicels twice as } \\
\text { long as the fruit. Fruit } \\
\text { ovoid, } 2 \text { mm long, } \\
\text { muricate; ridges not } \\
\text { prominent; stylopodium, } \\
\text { conical; styles c. mm long. }\end{array}$ \\
\hline $\begin{array}{l}\text { A. graveolens } \\
\text { L. }\end{array}$ & Sowa & Fruits & June-July & 126863 & $\begin{array}{l}\text { Antimicrobial, } \\
\text { antihyperlipidem } \\
\text { ic and } \\
\text { Antihypercholest } \\
\text { erolemic }\end{array}$ & $\begin{array}{l}50-150 \mathrm{~cm} \text { tall; strongly } \\
\text { scented. Leaves 3-4- } \\
\text { pinnate, segments filiform, } \\
\text { upper leaves shorter and } \\
\text { reduced. Peduncles up to } 15 \\
\mathrm{~cm} \text { long. Rays } 8 \\
\text { tonumerous. Pedicels } \\
\text { slender, c. } 4 \text { mm long. Fruit } \\
3-4 \text { mm long; dorsal and } \\
\text { intermediate ridges distinct, } \\
\text { lateral narrowly winged. }\end{array}$ \\
\hline $\begin{array}{l}\text { F. vulgare } \\
\text { Mill. }\end{array}$ & Saunf & Fruits & $\begin{array}{l}\text { July- } \\
\text { August }\end{array}$ & 12180 & $\begin{array}{l}\text { Carminative, } \\
\text { used for a variety } \\
\text { of problems like } \\
\text { digestion, } \\
\text { overweight, } \\
\text { boosting } \\
\text { metabolism and } \\
\text { for stomach } \\
\text { cramps, } \\
\text { purgative }\end{array}$ & $\begin{array}{l}\text { Plants perennial. Leaves } \\
\text { much dissected, 3-4- } \\
\text { pinnate; segments filiform } \\
\text { to linear. Bracts and } \\
\text { bractlets lacking. Peduncles } \\
\text { terminal and lateral Calyx } \\
\text { teeth obsolete. Petals } \\
\text { yellow. Fruit elliptic to } \\
\text { oblong, terete; stylopodium } \\
\text { conical; styles very short; } \\
\text { fruit ridges distinct; furrows } \\
\text { 1-vittate; commissure 2- } \\
\text { vittate. Inner seed face } \\
\text { plane to slightly concave. }\end{array}$ \\
\hline C. carvi $\mathrm{L}$. & Zeera & Fruits & June-July & 118455 & $\begin{array}{l}\text { Spice, an } \\
\text { infusion of fruits } \\
\text { and foliage is } \\
\text { used as } \\
\text { vermifuge and } \\
\text { digestive }\end{array}$ & $\begin{array}{l}\text { Perennial, up to } 70 \mathrm{~cm} \text { tall, } \\
\text { branched, glabrous. Root } \\
\text { fusiform, elongated. Leaves } \\
\text { bipinnatisect; segments } \\
\text { filiform to lanceolate or } \\
\text { oval, lower leaves petiolate, }\end{array}$ \\
\hline
\end{tabular}




\begin{tabular}{|c|c|c|c|c|c|c|}
\hline & & & & & & $\begin{array}{l}\text { upper sessile; bases } \\
\text { sheathing; sheath margin } \\
\text { white, membranous. } \\
\text { Involucre of 1-5 linear } \\
\text { bracts or lacking. Rays 5-9, } \\
\text { unequal. Involucel of } \\
\text { minute bractlets or lacking. } \\
\text { Flowers white or rose } \\
\text { colored. Calyx teeth } \\
\text { obscure. Fruit pedicels very } \\
\text { unequal. Fruit ovoid to } \\
\text { oblong, yellowish brown, } \\
\text { 3-4 mm long; ridges } \\
\text { prominent, obtuse; furrows } \\
\text { 1-vittate; commissure 2- } \\
\text { vittate. }\end{array}$ \\
\hline N. sativa $\mathrm{L}$. & Kalonji & Seeds & $\begin{array}{l}\text { February- } \\
\text { March }\end{array}$ & 10046 & $\begin{array}{l}\text { Carminative, } \\
\text { digestive, } \\
\text { antimicrobial } \\
\text { anti- } \\
\text { inflammatory, } \\
\text { anti-tumour, } \\
\text { anti-diabetic, } \\
\text { anti-ulcerogenic, } \\
\text { and anti-asthmic }\end{array}$ & $\begin{array}{l}\text { Rue, a hardy, evergreen, } \\
\text { somewhat shrubby plant. } \\
\text { The stem is woody in the } \\
\text { lower part, the leaves are } \\
\text { alternate, bluish-green, bi } \\
\text { or tripinnate, emit a } \\
\text { powerful, disagreeable } \\
\text { odour and have an } \\
\text { exceedingly bitter, acrid } \\
\text { and nauseous taste. The } \\
\text { greenish-yellow flowers are } \\
\text { in terminal panicles. Each } \\
\text { flower has a square of four } \\
\text { concave yellow petals with } \\
\text { wrinkled margins and with } \\
\text { eight stamens. The central } \\
\text { flower of the corymb has } \\
\text { five concave yellow petals } \\
\text { and ten stamens and often } \\
\text { is placed lower on the } \\
\text { flowering stalk than the } \\
\text { four-petaled flowers. The } \\
\text { first flower that opens has } \\
\text { usually five petals and ten } \\
\text { stamens, the others four } \\
\text { only and eight stamens. }\end{array}$ \\
\hline
\end{tabular}


Table 2. Quantitative and qualitative foliar cuticular features of the medicinal plants

\begin{tabular}{|c|c|c|c|c|c|c|c|c|}
\hline \multirow[b]{2}{*}{ Species } & \multicolumn{2}{|c|}{ Leaf epidermis (Ad/Ab) } & \multicolumn{3}{|c|}{ Trichomes } & \multicolumn{3}{|c|}{ Stomata } \\
\hline & Shape & $\begin{array}{l}\text { Margin/wall } \\
\text { morphology }\end{array}$ & $\begin{array}{c}\text { Length } \\
(\mu \mathrm{m})\end{array}$ & $\begin{array}{l}\text { Width } \\
(\mu \mathrm{m})\end{array}$ & $\begin{array}{c}\text { P/A } \\
\text { (Ab/Ad) }\end{array}$ & Type & $\begin{array}{c}\text { P/A } \\
(\mathbf{A b} / \mathbf{A d})\end{array}$ & $\begin{array}{c}\text { Type } \\
\text { (glandular/ } \\
\text { eglandular) }\end{array}$ \\
\hline C. roseus & $\begin{array}{l}\text { Irregular to } \\
\text { cuboidal/ } \\
\text { irregular } \\
\text { wavy, } \\
\text { variously } \\
\text { shape }\end{array}$ & $\begin{array}{l}\text { Thick, } \\
\text { straight }\end{array}$ & $\begin{array}{l}36 \text { to } \\
56\end{array}$ & $\begin{array}{l}25 \text { to } \\
30\end{array}$ & $\mathrm{Ab}$ & Anomocytic & Absent & Absent \\
\hline T. ammi & Irregular & Sinuous & $\begin{array}{l}13 \text { to } \\
16\end{array}$ & $\begin{array}{l}03 \text { to } \\
08\end{array}$ & $\mathrm{Ab}$ & Anomocytic & Absent & Absent \\
\hline $\begin{array}{l}\text { A. } \\
\text { graveolens }\end{array}$ & $\begin{array}{l}\text { Irregular } \\
\text { Sinuous } \\
\text { Polygonal } \\
\text { to cuboidal }\end{array}$ & Sinuous & $\begin{array}{l}50 \text { to } \\
75\end{array}$ & $\begin{array}{l}45 \text { to } \\
55\end{array}$ & $\mathrm{Ab}$ & Anisocytic & Absent & Absent \\
\hline F. vulgare & $\begin{array}{l}\text { Rectangula } \\
\text { r, } \\
\text { tubular, } \\
\text { Sinuous } \\
\text { cuboidalto } \\
\text { polygonal }\end{array}$ & Sinuous & $\begin{array}{l}13 \text { to } \\
16\end{array}$ & $\begin{array}{l}05 \text { to } \\
11\end{array}$ & $\mathrm{Ab}$ & Dicytic & Absent & Absent \\
\hline C. carvi & $\begin{array}{l}\text { Irregular } \\
\text { wavy }\end{array}$ & Sinuous & $\begin{array}{l}42 \text { to } \\
52\end{array}$ & $\begin{array}{l}25 \text { to } \\
31 \\
\end{array}$ & $\mathrm{Ab}$ & Anomocytic & Absent & Absent \\
\hline N. sativa & $\begin{array}{l}\text { Irregular } \\
\text { Somewhats } \\
\text { tellate }\end{array}$ & Sinuous & $\begin{array}{l}23 \text { to } \\
34\end{array}$ & $\begin{array}{l}05 \\
\text { to } \\
18\end{array}$ & $\mathrm{Ab} / \mathrm{Ad}$ & Anomocytic & Absent & $\begin{array}{l}\text { Unicellular, } \\
\text { glandular }\end{array}$ \\
\hline
\end{tabular}

Table 3. Quantitative and qualitative palyno-morphological of medicinal plants

\begin{tabular}{|c|c|c|c|c|c|c|}
\hline Species & $\begin{array}{c}\text { Pollen } \\
\text { type }\end{array}$ & $\begin{array}{c}\text { Pollen Size } \\
\text { (Length } \\
\times \text { Width) } \boldsymbol{\mu m}\end{array}$ & No. of Colpi & $\begin{array}{c}\text { Colpi } \\
\text { Length }(\boldsymbol{\mu m})\end{array}$ & $\begin{array}{c}\text { Pollen } \\
\text { class }\end{array}$ & $\begin{array}{c}\text { Exine } \\
\text { sculpturing }\end{array}$ \\
\hline C. roseus & Monad & $57.4 \times 37.5$ & Tri-colporate & $47.4 \mu \mathrm{m}$ & Prolate & Striate \\
\hline T. ammi & Monad & $13.7 \times 8.58$ & Bi-colporate & $8.63 \mu \mathrm{m}$ & Per-prolate & Striate \\
\hline A. graveolens & Monad & $20.9 \times 7.67$ & Bi-colporate & $12.6 \mu \mathrm{m}$ & Per-prolate & Psilate \\
\hline F. vulgare & Monad & $20.9 \times 9.6$ & Bi-colporate & $12.1 \mu \mathrm{m}$ & Per-prolate & Striate \\
\hline C. carvi & Monad & $20.8 \times 10.5$ & Bi-colporate & $12.0 \mu \mathrm{m}$. & Prolate & Reticulate \\
\hline N. sativa & Monad & $41.0 \times 34.6$ & Tetra-colporate & $27.9 \mu \mathrm{m}$ & Spheroidal & Perforate \\
\hline
\end{tabular}




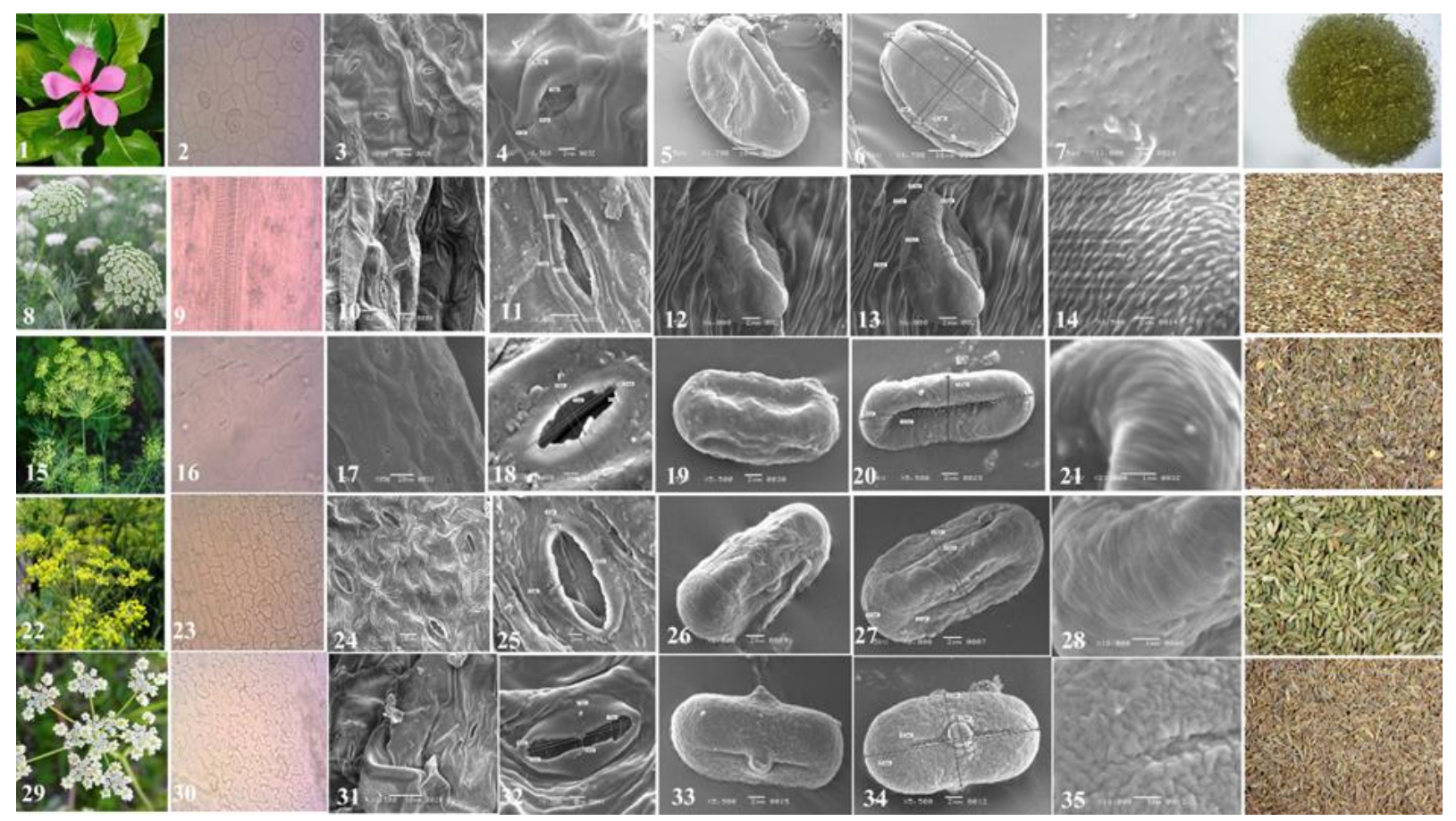

Figure 1. SEM images of stomata and pollen of different medicinal plants

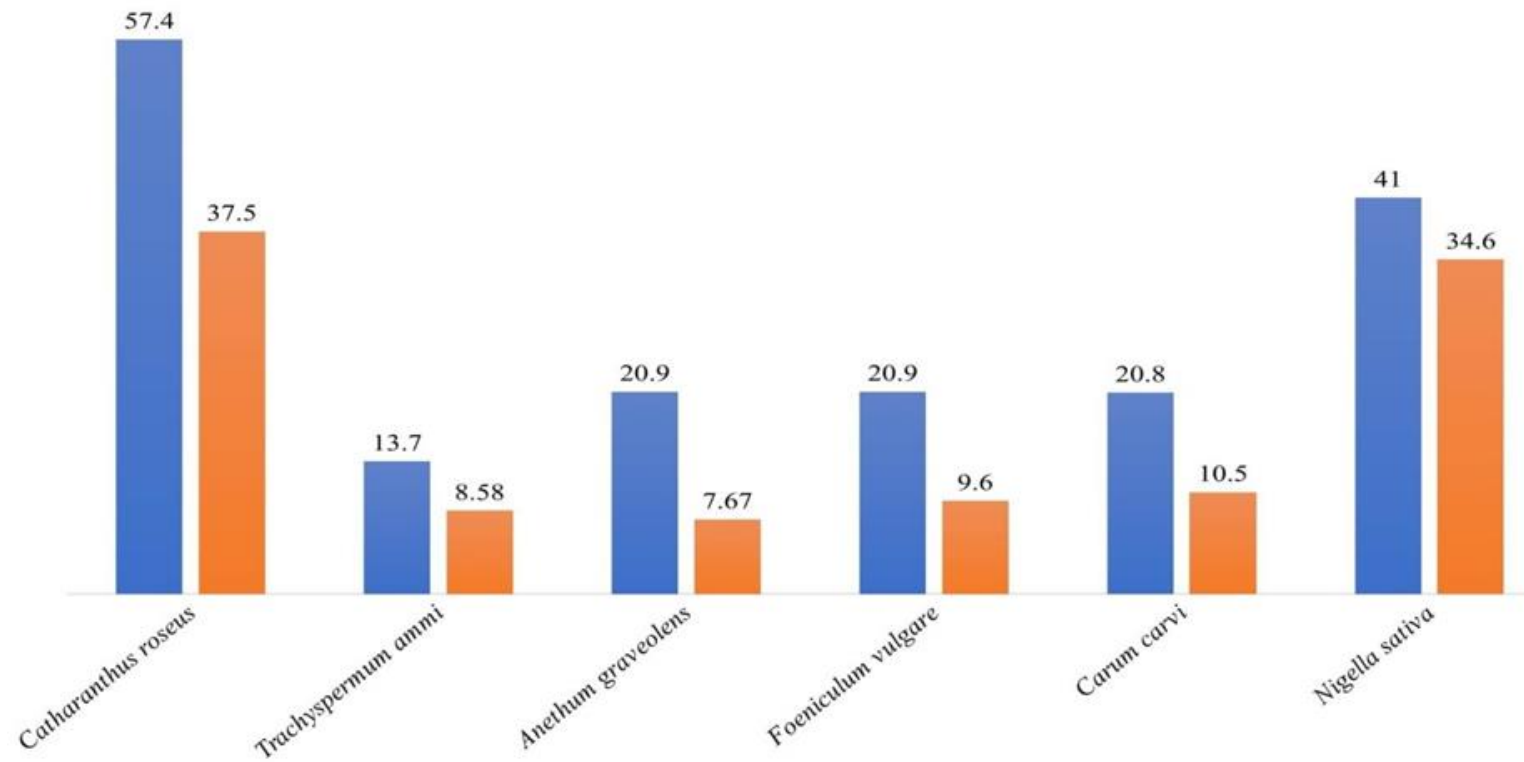

Figure 2. Percentage comparison in medicinal plants

\section{Conclusion}

Both leaf cuticular and Palynological characters were found useful in identification of medicinal plants. Different foliar cuticular and palynological characters in the taxonomic identification for pharmacognostic, physicochemical and ethnobotanical uses.

Authors' contributions

Designed \& idea of the work: N Seema, Supervision of the idea: M Hamayun \& A Ullah, Literature survey and graphs setting: 
M Zakaria, Manuscript writing and graphs setting: R Khan \& Omerkilic.

\section{References}

1. Khan $\mathrm{R}$ et al. (2018). Palynomorphological characteristics of gymnosperm flora of Pakistan and its taxonomic implications with LM and SEM methods. Microsco Res and Techniq 81(1): 74-87.

2. Jones JH (1986). Evolution of the Fagaceae: the implications of foliar features. Annals of the Missouri Botanical Garden, pp 228-275.

3. Khan R et al. (2017). Scanning electron and light microscopy of foliar epidermal characters: A tool for plant taxonomists in the identification of grasses. Microsco Res and Techniq 80(10): 1123-1140.

4. Guinet P (1962). Pollens d'Asie tropicale. Fasc. I. Trav. sect. sci. tech. Inst. fr. Pondichery 5: 1-8.

5. Marques M \& Melhem T (1966). Pollen grains of plants of cerrado. 11. Apocynaceae. Anais da Academia Brasileira de Ciências 38(2): 371.

6. Schill R \& Leuenberger B (1972). Pollenmorphologie und Cytotaxonomie der Gattung Pachypodium Lindl. Bot Jahrb 92(2-3): 169-177.

7. Van Campo M, Nilsson S \& Leeuwenberg AJ (1979).

Palynotaxonomic studies in Tabernaemontana L. sensu lato (Apocynaceae). Grana 18(1): 5-14.

8. Nilsson S \& Van Campo M (1978). Pollen morphological studies in the Apocynaceae with special reference to fine structure. in Fourth International Palynological Conference. Proceedings.

9. Willis JC (1973). A dictionary of the flowering plants and ferns. CUP Archive.

10. Mabberley DJ (1997). The plant-book: a portable dictionary of the vascular plants. Cambridge University Press.

11. Perveen A \& Qaiser M (2006). Pollen flora of Pakistan-XLVIII. Umbelliferae. Pak J of Bot 38(1): 1.

12. Reveal JL \& Jarvis CE (2009). Typification of names of temperate North American plants proposed by Linnaeus. Taxon 58(3): 977-984.

13. Dayrat B (2005). Towards integrative taxonomy. Biological $J$ of the Linnean Soci 85(3): 407-417.

14. Clarke J (1960). Preparation of leaf epidermis for topographic study. Stain Technol 35(1): 35-39.

15. Erdtman G (1952). Pollen morphology and plant taxonomy: An introduction to palynology. Angiosperms 1.

16. Erdman G (1969). Handbook of palynolgy: Morphology, taxonomy, ecology. An introduction to the study of pollen grains and spores. Hafner.

17. Moore PD, Webb JA \& Collison ME (1991). Pollen analysis. Blackwell Scientific Publications.

18. Punt W (1994.). Glossary of pollen and spore terminology. LPP Contributions series 1.

19. Nowicke J \& Skvarla J (1995). Pollen morphology. Engler, A, Prantl, K, (founders), Hiepko, P, (Ed.): Die natürlichen Pflanzenfamilien, 2nd edn, 17a IV, Ranunculaceae 129-159. 